Acta regionalia et environmentalica 2

Nitra, Slovaca Universitas Agriculturae Nitriae, 2013, p. 31-33

\title{
GRADIENT ANALYSIS OF IMPORTANCE OF SPONTANEOUSLY OCCURRING VASCULAR PLANT SPECIES IN ENERGY TREE AND GRASS STANDS
}

\author{
Alexander FEHÉR, Daniela HALMOVÁ, Lýdia KONČEKOVÁ \\ Slovak University of Agriculture in Nitra, Slovakia
}

\begin{abstract}
The paper focuses on a research carried out during two consecutive growing seasons (2011 and 2012) in a willow tree stand (Salix schwerinii $\times$ S. viminalis, variety Tordis) and a grass stand of miscanthus (Miscanthus $\times$ giganteus Greef et Deuter). Both of the species can be used for energy production. The evaluation was carried out in a research centre located in Kolíňany (Nitra district area, SW Slovakia). Biodiversity of the ground flora within the two crops stands was jointly assessed through the multivariate statistical method of Principal Components Analysis (PCA). The results showed that almost all spontaneous vascular plant species have a weedy character, they have no specific environment requirements, they are stress tolerant, and their propagules are often present in agricultural ecosystems or in vegetation of rural landscape (field margins, strip boundaries, abandoned fields, orchards, etc.). Good examples of synanthropic species observed in the stands are Cirsium arvense, Equisetum arvense, Convolvulus arvensis etc., while several other typical species of usually non-synanthropic, habitats, e.g. Symphytum officinale, Persicaria lapathifolia, Calystegia sepium were also observed. Many juvenile shrub and wood species occurring in E1 and E2 layers also belonged to the semi-natural vegetation, e.g. Sambucus nigra, Rosa canina agg., Crataegus laevigata. The presence of potentially invasive and expansive plant species is evaluated as a negative factor.
\end{abstract}

Keywords: energy crop, miscanthus, phytodiversity, short rotation coppice, willow

Due to the greenhouse gases emission from fossil fuels and the consequent global warming occurrence, current energy research is focused on the possibilities to use alternative energy resources. One of these resources is biomass, considered a renewable and "carbon neutral" energy feedstock. The production of biomass to be destined to energy-conversion processes should be derived from surplus agricultural lands (agricultural land available to non-food production) and from land requiring soil protection against erosion or improvement of microclimatic conditions. The amount of this land could be very different in different regions. In spite of the clear benefits showed by biomass crops (e.g. willows may have special effects and uses: phytoremediation, bioengineering and biomass production for both fuel and fiber, cf. analysis of Kuzovkina and Quigley, 2005), there is a lack of knowledge about their ecological and environmental impacts, including effects on the biological diversity of plants in agricultural landscape (Dale et al., 2010; Dauber et al., 2010a, 2010b). Volk et al. (2004) indicated that woody energy crops enhance biodiversity and willow crops provide diverse habitats at landscape level (the combination of different varieties and growth stages creates a structurally diverse habitat for a range of wildlife - shrub, open habitat, etc.). On the other hand, weed competition causes yield losses of energy crops (Sage, 1999). In Slovakia, there are only few data on impacts of energy plantations on local biodiversity (Fehér, Halmová and Končeková, 2012; Končeková, Halmová and Fehér, 2012; Lutková et al., 2012). Our paper evaluates the biodiversity of ground flora in both a woody short rotation coppice of willow (Salix schwerinii $\times S$. viminalis, variety Tordis) and a grass stand of miscanthus (Miscanthus $\times$ giganteus, Greef et Deuter) in the environmental conditions of SW Slovakia.

\section{Material and methods}

The trial was carried out on an agricultural land located in the research centre in Kolínany (Nitra district area, SW Slovakia, $180 \mathrm{~m}$ a.s.l., warm and dry climate with average annual temperature $9.6^{\circ} \mathrm{C}$ and rainfall $560 \mathrm{~mm}$, fluvial soils). The crop stands were established in 2009 (willow) and 2010 (miscanthus). The survey was performed during two consecutive growing seasons (in 2011 and 2012 in 14 days intervals) on two crop stands: a tree plantation of Swedish willow variety "Tordis" and a grass stand of the hybrid Miscanthus $\times$ giganteus. Each plant stand had a total extent of $75 \mathrm{~m}^{2}$ while the area of tthe sampling plots was $25 \mathrm{~m}^{2}$ ). In the sampling survey the presence of species and their relative abundance were measured (Braun-Blanquet, 1964).

Gradient analysis of environmental interactions of both selected energy plants ("samples" - sample 1: miscanthus in 2011, sample 2: miscanthus in 2012, sample 3: willow variety Tordis in 2011) and spontaneously occurring herbs ("species") was made by multivariate ordination methods by means of the PC program Canoco for Windows version 4.5. The interaction values accounted for (eigenvalues) have been visualized by CanoDraw for Windows 4. The method used for biodiversity evaluation was chosen for linear and statistically indirect interactions (principal component analysis, P(A) between the coefficient of importance of spontaneous plants (abundance $\times$ class of species persistence) and energy plants.

The species data have not been transformed; neither species nor samples were weighed. The species have not been centered (standardized) but we centered the samples. The total sum of squares was 178,519 and a standard deviation of 35.582 in the species data was detected. After 
computing the eigenvalues and the cumulative percentage of variances in the species data, the first two principal components were selected and results were presented in a biplot.

\section{Results and discussion}

The results showed that almost all spontaneous vascular plant species had a weedy character, they have no specific environment requirements (i.e. they are generalist species with a wide-range of ecological valence), they are stress tolerant and their propagules are often present in agricultural ecosystems or, more in general, in vegetation of rural landscape (47 species of field margins, strip boundaries, abandoned fields, orchards, etc. were totally selected). Good examples of them are Cirsium arvense, Equisetum arvense, Elytrigia repens and Convolvulus arvensis etc. Only few species are typical for other, usually nonsynanthropic habitats, e. g. Symphytum officinale, Persicaria lapathifolia, Calystegia sepium. Many juvenile shrub and wood species occurring in E1 and E2 layers also belonged to the semi-natural category, e. g. Sambucus nigra, Rosa canina agg., Crataegus laevigata, Prunus spinosa, Cerasus avium and Swida sanguinea. Presence of potentially invasive and expansive plant species (Conyza canadensis, Stenactis annua, Galinsoga parviflora, Lycium barbarum) is evaluated as a negative factor. Occurrence, growth and life cycle of spontaneous species have been partially affected by the specific ecological features of the energy crop stands (changes in light penetration through the canopy and light intensity near the ground during the growing season, soil water balance and the resulting water availability, nutrient competition, etc.). All these factors together have probably determined changes in the phenotypic plasticity of plant organs, in the phenology of species, in the vitality and development of generative organs.

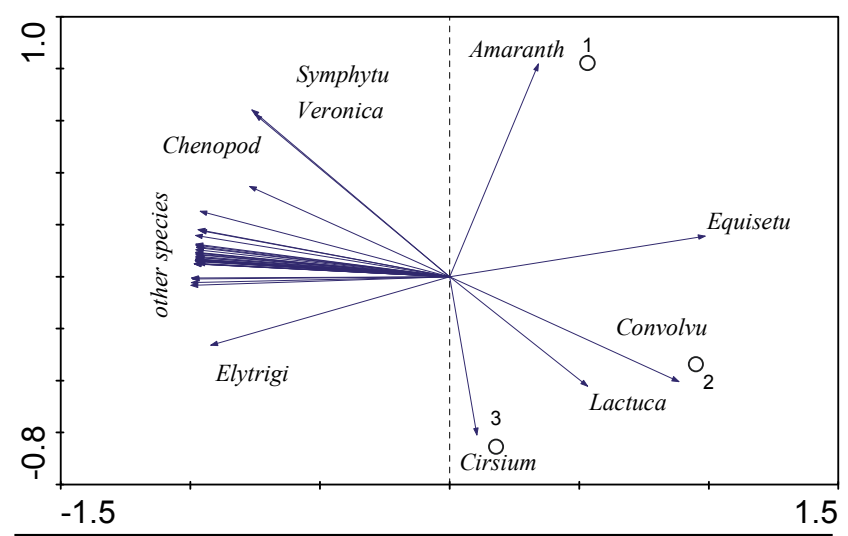

Figure 1 Principal components analysis (PCA) of relationships between energy crops and their ground flora species

1 - Miscanthus in 2011, 2 - Miscanthus in 2012, 3 - Salix, variety Tordis in 2011, Amaranth - Amaranthus retroflexus, Equisetu - Equisetum arvense, Convolvu - Convolvulus arvensis, Lactuca-Lactuca serriola, Cirsium-Cirsium arvense, Elytrigi-Elytrigia repens, Chenopod - Chenopodium album, Symphytu - Symphytum officinale, Veronica - Veronica persica
The abundance of spontaneous species was in the range of values from 1 to 5 (according to the Braun-Blanquet scale), the highest scores (soil cover) were measured with respect to Cirsium arvense, Equisetum arvense, Convolvulus arvesnis, casually Amaranthus retroflexus was important. The gradient analysis showed that a high share of species (but not all of them) has not a significant specific relation to years of observation (their occurrence has not been influenced significantly by meteorological conditions in different years) or to the specific identity of the energy crops (they have comparable occurrence in stands of both energy herbs and coppices). Surprisingly, considering the small deviations in importance of spontaneous species in different observations, the difference in biodiversity is higher between the first and the second year of observations in stands of miscanthus than between herb layers of willow stands in the first year and miscanthus stands in the second year (it means that current meteorological conditions are more important than the taxonomic or genetic identity of energy crops). In the second year of study, as many as 8 species of low importance disappeared from miscanthus stands in comparison with the species composition in the first year (37.9\%) but 4 newcomers occurred $(19.0 \%)$. In the first year, the difference between the samples in miscanthus and the fast growing willow variety Tordis was high: 19 species found in the stands of miscanthus were not present in the willow stands (65.5\%) and 12 species from willow stands absented in the stands of miscanthus (52.2\%). A high percentage of differences in species composition has been eliminated by low abundance and low frequency of majority of species. The disappearing species and new-comers had only minimum importance with no or temporal influence on aspects of phytocoenoses.

Principal components analysis showed a weak relationship between occurrence of spontaneous plant species and years of observation of energy plant species, except of five weed species (Fig. 1). Power of influence of "samples" was balanced. More effective influence was observed in the sample 1 and less effective in the sample 3. Amaranthus retroflexus had a clear correlation with miscanthus in the first year; a casual one in the second year, and was not observed at all in the willow stands. Such sudden changes in frequency of therophytes are not rare; the pigweed recedes as a result of the light deficit. Equisetum arvense was strictly associated with the stands of miscanthus with a minimum difference between the years (it is a perennial with high persistence). In this case, beside the effect of the crop covering, one more fact should be considered: there is a higher ground-water level and probably the soil reaction ( $\mathrm{pH}$ value) is lower on the area cropped with miscanthus (the presence of horsetail species indicates acid soils or nitrogen deficiency). Both Convolvulus arvensis and Lactuca serriola were common in miscanthus stands mainly in the second year of study, less frequent in willow stands. This phenomenon can be explained by weather conditions in two different years and as a result of the succession phase. Cirsium arvense was a typical weed in willow stands; conversely, it was rare in miscanthus stands during both years. This can be a result of the age of willow stands which are older than the miscanthus cover (Cirsium arvense is a perennial with an optimum growth 
in later succession phases). A more intensive expansion of this species can be predicted in the stands of miscanthus, if no specific above-ground or under-ground competition mechanisms will limit its spreading.

A minimum, though measurable difference with other species was observed considering Veronica persica, Symphytum officinale, Chenopodium album and Elytrigia repens (they have affinity to certain type of energy crops or weather conditions in different years of study). Absolute values of their importance might be robust in several field records (including also their absence in certain variants) but they were less relevant or negligible in comparison with the higher values of the coefficient of importance of dominant species.

In certain countries, weeds of arable crops are the most threatened and their ecological niches (like field margins, etc.) are usually priority habitats for nature conservation; as a result, short rotation coppice can support these biodiversity targets (c. f. in UK: Fry and Slater, 2009). In other countries, only few species with conservation status are found in short rotation coppice (Gustaffson, 1987). In our research, no rare or protected plantswere found.Theassessment of environmental impacts of short rotation coppice is very difficult but the definition of its model is in process of development (c. $f$. preliminary results based on data from Sweden and Germany, as reported by Langeveld et al., 2012). Particularly, the age of plantations, irradiance and soil nutrient contents influence the species composition (phytodiversity) in woody energy plantations (Baum, 2012). The case of energy Miscanthus is similar to the Salix stands; its phytodiversity is rich in weeds with a clear field margin effect (Semere and Slater, 2007). These authors also observed that the most dominant plant species in miscanthus crop fields were (in decreasing order of percentage ground cover): Elytrigia repens, Poa annua, Bromus sterilis, Galium aparine, Viola arvensis, Cirsium arvense, Fumaria officinalis, Fallopia convolvulus, Senecio vulgaris, Veronica spp. and Agrostis canina. Clapham and Slater (2008) recorded 31 weed species within miscanthus plantation, with Epilobium montanum, Rumex obtusifolium and Ranunculus repens the most frequently observed.

\section{Conclusions}

The ground flora of energy plantations is predominantly composed of synanthropic plants having clear weedy character. There are differences in phytodiversity among different years and crops, but the basic character of spontaneous vegetation is quite stable. This fact should be considered when developing management strategies on energy crops cultivation (with respect to nature conservation, weed control, etc.).

\section{Acknowledgements}

This work was supported by the Slovak Grant Agency for Sciences (VEGA) Grant No. 1/1220/12, Grant No. 1/0942/12 and FP7-REGPOT-2011-1 STAR-AgroEnergy.

\section{References}

BAUM, S. 2012. Phytodiversity in short rotation coppice plantations. Dissertation zur Erladung des Doktorgrades. Fakultät für Forstwissenschaften und Waldökologie. Göttingen : Georg-August-Universität, 2012. p. 99.
BRAUN-BLANQUET, J. 1964. Pflanzensoziologie, Grundzüge der Vegetationskunde. Wien : Springer Verlag, 1964. p. 865.

CLAPHAM, S. J. - SLATER, F. M. 2008. The biodiversity of established biomass grass crops. In: Aspects of Applied Biology, Biomass and energy crops III (eds: BOOTH, E. - GREEN, M. KARP, A. - SHIELD, I. - STOCK, D. - TURLEY, D, AAB conference, 10-12 December 2008., Sand Hutton, UK), p. 325-329.

DALE, V. H. - LOWRANCE, R. - MULHOLLAND, P. - ROBERSTON, G. P. 2010. Bioenergy sustainability at the regional scale. In: Ecology and Society, vol. 15, 2010, no. 4, p. 23.

DAUBER, J. - EMMERSON, M. - JONES, M. - STOUT, J. C. 2010 a. Strategic overview of influences of biomass crop production on biodiversity and ecosystems services in Ireland. Simbiosys. EPA founded project (report), 2010, $12 \mathrm{p}$.

DAUBER, J. - JONES, M. B. - STOUT, J. C. 2010b. The impact of biomass crop cultivation on temperate biodiversity. In: Global Change Biology Bioenergy, vol. 2, 2010, p. 289-309.

FEHÉR, A. - HALMOVÁ, D. - KONČEKOVÁ, L. 2012. Spontaneous associated plants in short rotation coppice: challenge for invaders. In: Neobiota 2012. León : GEIB Grupo Especiale en Invasiones Biológicas, 2012, p. 330.

FRY, D. - SLATER, F. 2009. The biodiversity of short rotation willow coppice in the Welsh landscape. In: A report to the Institute of Biological, Environmental and Rural Sciences, Aberyswyth University for EU Project “Willows for Wales", 2009, 31 p.

GUSTAFFSON, L. 1987. Plant conservation aspects of energy forestry - a new type of land use in Sweden. In: Forest Ecology and Management, vol. 21, 1987, p. 141-161.

KONČEKOVÁ, L. - HALMOVÁ, D. - FEHÉR, A. 2012. Occurrence of spontaneous herbaceous vegetation in stands of Miscanthus $\times$ giganteus. In: Climate change, economic development, environment and people conference. Prešov : Prešovská univerzita, 2012, p. 171-175.

KUZOVKINA, Y. A. - QUIGLEY, M. F. 2005. Willows beyond wetlands: uses of Salix L. species for environmental projects. In: Water, Air, and Soil Pollution, 2005, no. 162, pp. 183-204.

LANGEVELD, H. - QUIST-WESSEL, F. - DIMITRIOU, I. et al. 2012. Assessing environmental impacts of short rotation coppice (SRC) expansion: model definition and preliminary models. In: Bioenergy Research, vol. 5, 2012, p. 621-635.

LUTKOVÁ, M. - FEHÉR, A. - HALMOVÁ, D. - KONČEKOVÁ, L. 2012. Biodiversity of sponataneous vegetation in short rotation coppice of hybrid Populus $\times$ canescens. In: Climate change, economic development, environment and people conference, 2012, pp. 177-181.

SAGE, R. B. 1999. Weed competition in willow coppice crops: the cause and extent of yield losses. In: Weed Research, vol. 39, 1999, pp. 399-411.

SEMERE, T. - SLATER, F. M. 2007. Ground flora, small mammal and bird species diversity in miscanthus (Miscanthus $\times$ giganteus) and reed canary-grass (Phalaris arundinacea) fields. In: Biomass and Bioenergy, vol. 31, 2007, pp. 20-29.

VOLK, T. A. - VERWIJST, TH. - THARAKAN, P. J. - ABRAHAMSON, L. P. - WHITE, E. H. 2004. Growing fuel: a sustainability assessment of willow biomass crops. In: Frontiers in Ecology, vol. 2, 2004, no. 8, pp.411-418.

Contact address:

Alexander Fehér, Slovak University of Agriculture in Nitra, Faculty of European Studies and Regional Development, Department of Sustainable Development, Mariánska 10, 94901 Nitra, Slovak Republic, e-mail: alexander.feher@ uniag.sk 